\begin{abstract}
A Review
ADVANCE RESEARCH JOURNAL OF

C R (9) $\mathbf{P}$

I M P R O V E M E N T

Volume 7 | Issue 2 | December, 2016 | 245-250

$\bullet \bullet$ e ISSN-2231-640X

\section{Weed menace and nature of weed-crop competition in perspective of Bihar}

DOI :

10.15740/HAS/ARJCI/7.2/245-250

Visit us: www.researchjournal.co.in

Author for correspondence: RABINA GUPTA

Tirhut College of Agriculture (Dr. RPCAU) Dholi,

MUZAFFARPUR (BIHAR) INDIA

Email: rabinatca@gmail.com

\author{
RABINA GUPTA
}

\begin{abstract}
Of the more than 300,000 species of plants known in the world, hardly 3,000 are of economic value to us. When one grows any of these economic species of plants, invariably, a variety of volunteer vegetation comes up simultaneously which is competitive and undesirable. This results into competition that is defined as the action of endeavoring to gain what another endeavors to gain at the same time. Among plant communities each plant is in a state of continuous competition with its neighboring plants for various growth elements, both above and under the ground. Volumes of research into the primary elements of weed-crop competition have drawn our concern to mineral nutrients, moisture and light. Weed-crop competition for ground space is not usually upheld by the modern researchers.
\end{abstract}

KEY WORDS : Allelopathy, Competition, Menace, Weeds, Yields

How to cite this paper : Gupta Rabina (2016). Weed menace and nature of weed-crop competition in perspective of Bihar. Adv. Res. J. Crop Improv., 7 (2) : 245-250, DOI : 10.15740/HAS/ARJCI/7.2/245250.

Paper History : Received : 17.10.2016; Accepted : 30.11 .2016 